\title{
水質計測のためのソリッドステート化学センサ
}

\section{ISFET イオンセンサ}

\section{勝 部 昭 明*}

\section{1.は．じめに}

ISFET(Ion Sensitive Field Effect Transisitor)は溶液の $\mathrm{pH}$ やイオン濃度を測定することのできる微小固体センサで ある・1970年 Bergverdによって ISFET の原理が発表され てから多くの研究が行われ(1)，イオンセンサの他ガスセンサ やバイオセンサなど多くの化学センサが開発された。 そのう ち $\mathrm{pH}$ センなどはすでに実用化されている. ISFET はシ リコン集積回路技術を活用した固体センサであるため, 従来 のガラス電極やイオン選択性電極に比べると, (1)微小化が容 易であること，(2)高速にできること，(3)絶縁性の感応膜を使 用できること，(4)電子回路を同一基板上に搭載でき多機能化 ができること，(5)特性のそろったセンサを大量に生産可能で あること, などの特徵を持つ.

このように多くの利点を持つが，一方イオンセンサは溶液 の中に入れて使用されるため溶液からの絶縁や腐食などに対 する十分な保護が必要となる，このため実用的なセンサを開 発するにあたっては, 出力の安定化にかかわる研究が必要で ある. 本稿では ISFET イオンセンサの代表的な開発例を示 すとともに実用化をターダットとした研究例を紹介する.

\section{ISFET の 構 造}

図 1 に ISFET の基本構造を示す. MOSFET のゲート金 属をイオン感応物質に置き換えた構造をもつものである. 参 照電極にバイアスをかけて FET のチャネルを導通状態にし ゲート絶縁膜表面に発生する電圧変化をチャネルコンダクタ

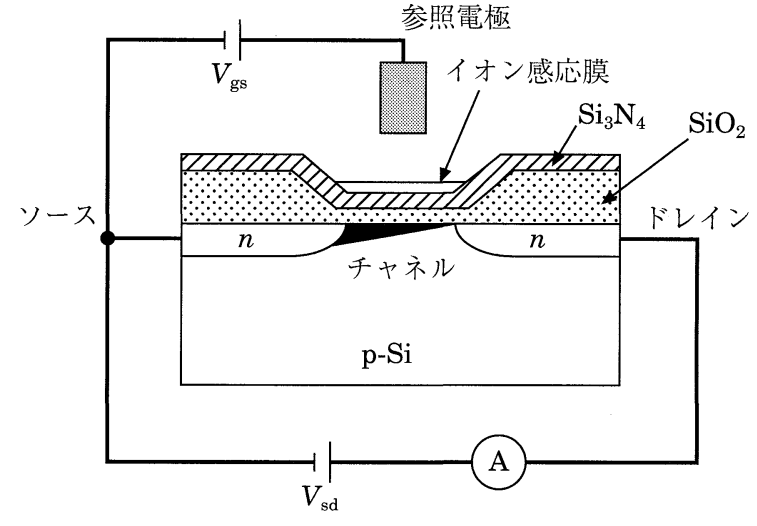

図 1 ISFET の基本構造.

ンスの変化から測定するものである. ゲート絶縁膜表面にイ オン感応材料を薄膜状に固定化することにより種々のイオン センサが製作できる。

ISFET は溶液中で使らため，素子を溶液から絶縁する必 要がある。また溶液からの腐食の防止も重要である。このた めセンサの構造や封止のための工夫が必要であり, 次のよう な手法が開発されている。(1)センサ全体を絶縁膜で覆ら方 法 (2)，(2) PN 接合分離を用いる方法 ${ }^{(3)}$ ，(3) SOS 基板や， SIS 基板を使ら方法 ${ }^{(4)}$ ，(4)素子の裏側からドレイン，ソース のコンタクトをとる方法(5). 図 2 はシリコンを針状に加工し て先端に ISFETをつくり, 全体を絶縁膜で覆った微小セン サである. 先端が $10 \mu \mathrm{m}$ 以下のものも作られている. 図 3 に接合分離型 ISFET の構造を示す．素子はシリコンから二 重の PN 接合で絶縁がとってあり, 表側もゲート感応部以外

* 埼玉大学教授; 工学部情報システム工学科 (テ338 浦和市下大久保255)

ISFET Ion Sensor; Teruaki Katsube(Department of Information and Computer Sciences, Faculty of Engineering, Saitama University, Urawa)

Keywords: ion sensitive field effect transistor, chemical sensor, ion sensitive membrane, semiconductor sensor, solid state chemical sensor, PH sensor

1995年 9 月 7 日受理 
はポリシリコンで覆われた構造になっている.このため溶液 との電気的絶縁は良好で, 漏れ電流は $1 \mathrm{nA}$ 以下であり電解 液中での動作は安定している. 図 4 に SOS 基板を用いた ISFET を示す. これはISFET が 4 個集積化されたものであ るが，素子の基板側は耐腐食性のサファイアで保護されて拉 り溶液中で使うのに適した構造である. 図 5 は SIS $(\mathrm{Si} / \mathrm{Insu}$ lator $/ \mathrm{Si}$ ) 基板を使ったものであるが，素子は上側の Si に作 り, 異方性エッチングにより下側の $\mathrm{Si}$ 削りゲートは下側 に,ソース・ドレインは上側(溶液に接しない側)にとったも のである. SOS 構造と同じく素子は中央の絶縁膜で溶液か ら保護されて括り，配線がとりやすい構造になっている。

\section{3. pHISFET}

$\mathrm{pH}$ センサでは感応膜として $\mathrm{SiO}_{2}, \mathrm{Al}_{2} \mathrm{O}_{3}, \mathrm{Si}_{3} \mathrm{~N}_{4}{ }^{(6)}, \mathrm{Ta}_{2} \mathrm{O}_{5}{ }^{(7)}$

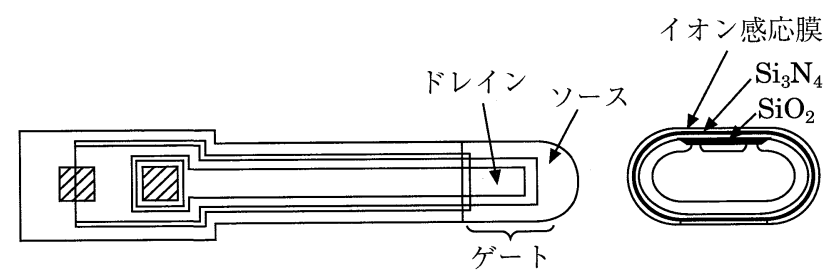

図 2 微小に加工し全体を絶縁膜で保護した ISFET.

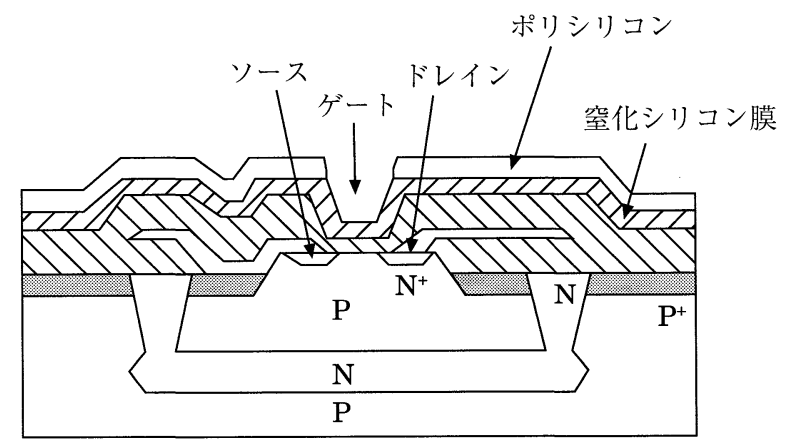

図 3 接合分離型 ISFET の構造.

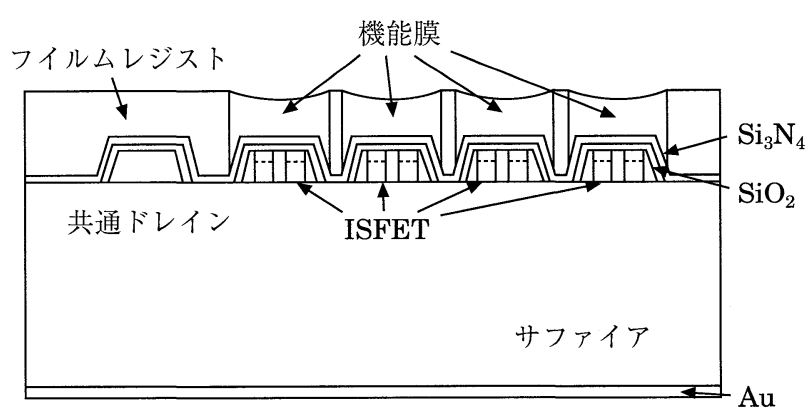

図 4 SOS 基板を用いた集積化 ISFET.

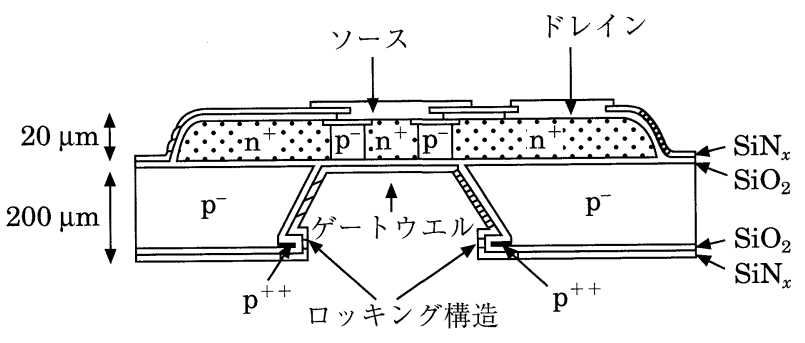

困 5 SIS 構造を用いた ISFET.

などの絶縁膜が使われる，溶液中では，これらの膜の表面に ヒドロキシ基が発生し，これと水素イオンとの平衡反応によ って界面電圧が変化する. このゲート電圧の変化が電界効果 によって FET のチャネルコンダクタンスを変化させ, 出力 電流に変換される. 絶縁膜には, 初期には $\mathrm{SiO}_{2}$ が使われた が， $\mathrm{SiO}_{2}$ はイオン透過性が大きく，応答のドリフトも大き く実用的には問題がある. 現在は $\mathrm{Si}_{3} \mathrm{~N}_{4}$ や $\mathrm{Ta}_{2} \mathrm{O}_{5}$ が最も広 く使われている. これらの膜は RF スパッタ法や化学気相成 長法(CVD 法)で作られる．最近はより欠陥の少ない膜をつ くるため, 低温で成膜可能な, プラズマ CVDや光励起 CVD, LPCVD 法(低圧 CVD 法) (6) など新しい方法が使われ るよらになっている。これらの方法で作られた $\mathrm{Si}_{3} \mathrm{~N}_{4}$ 膜や $\mathrm{Ta}_{2} \mathrm{O}_{5}$ 膜はほぼネルンスト応答を示し, $298 \mathrm{~K}$ での $\mathrm{pH}$ 感度 は $\mathrm{Si}_{3} \mathrm{~N}_{4}$ では 50〜 $55 \mathrm{mV} / \mathrm{pH}, \mathrm{Ta}_{2} \mathrm{O}_{5}$ では 55〜 $58 \mathrm{mV} / \mathrm{pH}$ で ある. 応答速度は数 $\mathrm{ms}$ 程度で極めて早い. 出力のドリフト も最近改善されてきて拈り，3.6 ks $(1 \mathrm{~h})$ 当り $0.1 \mathrm{mV}$ 以下に なっている。

一方 ISFET と組合せて使う参照電極も小型化が行われて いる. しかし従来の銀塩化銀電極の小型化には限界があるた め, IC 技術と適合性のある参照電極も開発されている. 図 6 は $\mathrm{Si}$ 基板に異方性エッチングでマイクロプールを作りこ の中に $\mathrm{KCl}$ やハイドロゲルを満たした構造の微小電極であ

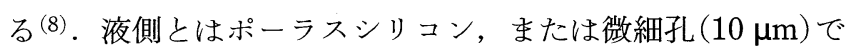
コンタクトをとる. 容量 $0.1 \mathrm{~mm}^{3}$ のもので, ドリフト 0.028 $\mu \mathrm{V} / \mathrm{s}$ の特性が報告されている。 また全固体センサの製作の ために $\mathrm{pH}$ 不感応性の ISFET(REFET)が研究されている.

図 7 に示すように ISFET との差を測定するものである. IC 技術により特性のそろったFETを作製することによりドリ フトや雑音なども相殺できる. 参照電極としても, 表面電位 が 2 つ FET で打ち消し合うので金属電極を使うことがで きる. $\mathrm{pH}$ 不感応性の材料としてパリレン, テフロン，ポリ スチレン等が試みられている.ゲートの $\mathrm{SiO}_{2}$ 表面に長鎖ア ルキルシランを固定化して $\mathrm{pH}$ 感度をコントロールしようと する試みもある(9).

現在 ISFET は米国，ヨーロッパ，日本で各々数社から市 販され，FET の知識が特になくても手軽に使えるようにな っている. 製品によって若干異なるが簡単な校正を行うこと により $\mathrm{pH} 1 \sim 12$ で精度 $0.1 \sim 0.01 \mathrm{pH}$ 程度の特性を持つ. 図 8 に新電元工業製の pHISFET を示す. 


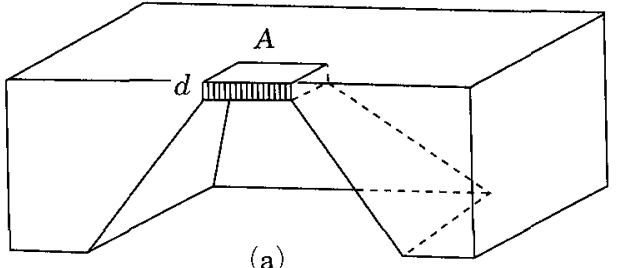

(a)

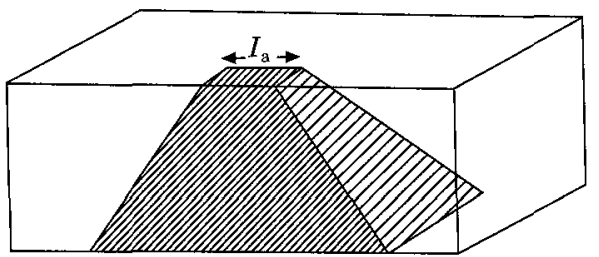

(b)

図 6 (a) 多孔質, (b) 微小孔, をる微小参照電極.

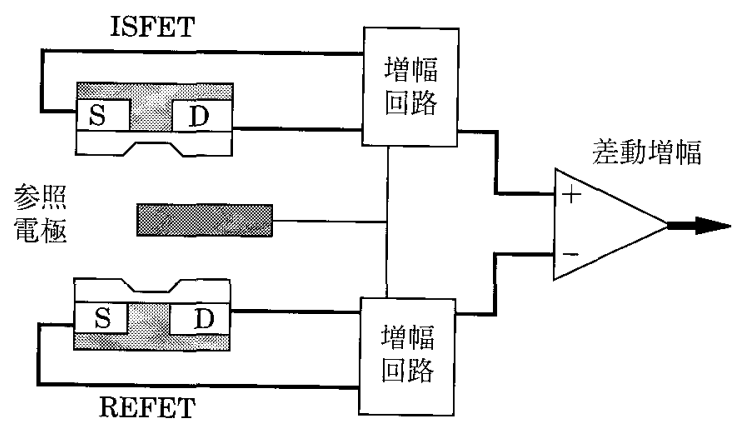

図 7 不感応性 ISFET(REFET)を用いた ISFET の美 動測定法.

\section{4. 各種の ISFET イオンセンサ}

ゲート絶縁膜上にイオン感応性薄膜を固定化することによ りさまざまなイオンセンサが開発されている，イオン感応膜 の製作法には, 真空蒸着法やスパッ夕法, 気相化学成長 (CVD) 法などのドライ法とキャスト法, ディップコート法 などのウェット法がある. ドライ法による膜形成技術は半導 体技術の発展とともに進歩して和り，デバイス製作技術との 適合性もすぐれた方法である。しかし高温処理やイオン衝撃 を伴らことが多いため扱うことのできる材料の種類が制限さ れ無機系の材料が主となる。これ対し，ウェット法では多 種類のイオン感応材料を活用でき, ニュートラルキャリアや イオン交換体を含む有機膜を用いて多くのセンサが提案され ている.しかし有機材料をウェット法でがート絶縁膜上につ ける技術は通常の半導体デバイス製造プロセスとはなじみに くいものであり，その開発のためには解決すべき課題も多 い.表 1 にドライ法で作成されたイオンセンサの例を示す。 これらは主に真空蒸着法や高周波スパッ法で作られてい る。ただしNASガラス膜は金属アルュレート加水分解法 ${ }^{(2)}$

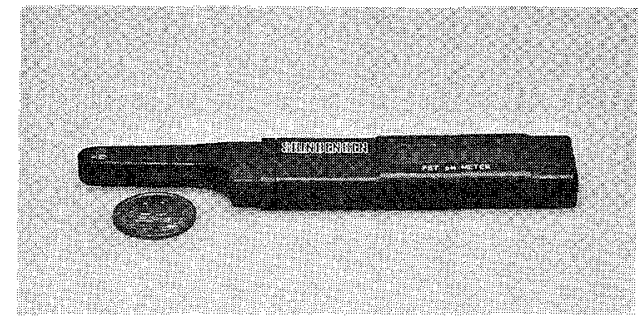

図 8 市販されている pHISFET.

やイオン打ち込み法で作られる。イオン打ち込み法は，Na や $\mathrm{Al}$ などを $\mathrm{SiO}_{2}$ 中に打ち込んで絶縁膜表面改質するも のである。この手法によれ礼, 組成の精密な制御が可能で, またイオン感度を組成比によってコントロールすることも可 能である(10).

有機材料ではドライ法で作られるるのは限られているが， 最近カリックスアレンの真空蒸着膜を用いた $\mathrm{Na}^{+}, \mathrm{Co}^{2+}$ セ ンサが報告されている(15)．また FET のゲートにCuを真空 蒸着でつけ, TCNQ(テトロシアノキノジメタン)のアセトニ トリル溶液に浸して形成した $\mathrm{Cu}(\mathrm{I}) \mathrm{TCNQ}$ を用いた $\mathrm{Cu}^{2+}$ イオンISFET の報告もある(16).

有機膜を用いた ISFET の多くは，ポリマー等の支持膜に イオン感応材料を固定して作られる.この手法以よれば，イ オン選択性電極で開発さ机た多種の材料が使用可能である. このため，医用や環境計測などを目的として多くのセンサが 提案されている(表 2 参照). しかし実用化似関して課題も市 る. そのらち最も重要な問題はイオン感応膜の安定な固定化 である。帛た IC 技術之適合性のある製膜技術の開発も必要 である.この種のセンサはJanataらによって最初に提案さ れたもので(24)，有機支持膜としては，可塑剤を含んだポり 塩化ビニル(PVC)が使われた。しかし PVCを用いたイオン 七ンサは, ゲート絶縁膜との密着性が良くなく，例離が和き やすい，立た固定化膜はきわめて薄いのでイオノフォアや可 塑㨈が徐々に流出することなどの問題がある。このため寿命 に限界がある。こ机らを解決するため保留性の高いイオン 感応膜の研究が活発に行われている. これらの中には，(1)イ オン感応膜を機械的に支持する方法, (2)光硬化性の樹脂を用 いて架橋する方法，(3)ゲート絶縁膜と密着性のよい有機膜を 使う方法, (4) イオン感応材料を化学結合に上り高分子膜に結 合する方法などがある。適当な可塑剤を選ぶことも重要であ $ろ^{(17)}$.

また，PVC膜をゲート絶縁膜である窒化ケイ素膜上に直 接コーティングすると，膜中を炭酸ガスや有機イオンが透過 $し て$, 窒化ヶイ素膜近傍での $\mathrm{pH}$ 変化により絶緑膜/有機膜 界面の電位が変動するといら問題がある。この問題を解決す るため絶縁膜と有機膜の間汇緩衝液を含んだハイドログルを 介在させた ISFET (25)や窒化ケイ素膜上に銀, 塩化銀の層を 形成させて，その上に PVC 膜をキャストしたISFETが提 
表 1 ドライ法で作製したISFETイオンセンサ.

\begin{tabular}{l|l|l|c}
\hline \hline 測定イオン & \multicolumn{1}{|c|}{ イオン感応膜材料 } & \multicolumn{1}{|c|}{ 製膜 法 } & 文献 \\
\hline $\mathrm{Na}^{+}$ & $\mathrm{NAS}$ ガラス & イオン打ら达み & 10 \\
$\mathrm{I}^{-}$ & $\mathrm{AgI}$ & 真空蒸着 & 11 \\
$\mathrm{~F}^{-}$ & $\mathrm{LaF}_{3}$ & 真空烝着 & 12 \\
$\mathrm{Cu}^{2+}$ & カルュゲナイドガラス & スハッッタリン゙ & 13 \\
$\mathrm{I}^{-}, \mathrm{SCN}^{-}$ & 無アルカリ鉛ガラス & スパッリング & 14 \\
$\mathrm{Na}^{+}, \mathrm{Co}^{2+}$ & カリックスアレン & 真空蒸着 & 15 \\
$\mathrm{Cu}^{2+}$ & $\mathrm{Cu}(\mathrm{I}) \mathrm{TCNQ}$ & 真空蒸着 & 16 \\
\hline
\end{tabular}

表 2 有機膜 ISFET イオンセンサ.

\begin{tabular}{|c|c|c|}
\hline 測定イオン & イオン感応膜材料 & 文献 \\
\hline $\begin{array}{l}\mathrm{K}^{+} \\
\mathrm{Na}^{+}\end{array}$ & $\begin{array}{l}\text { バリノマイシン } \\
\text { ビスクラウンエーテル誘道体 }\end{array}$ & $\begin{array}{r}5 \\
17\end{array}$ \\
\hline $\mathrm{Ca}^{2+}$ & $\begin{array}{l}\text { 非環状ポリエーテルアミド誘導 } \\
\text { 体 }\end{array}$ & 18 \\
\hline $\mathrm{NH}_{4}^{+}$ & ノナクチン & 19 \\
\hline $\mathrm{Cl}^{-}$ & テトラセチルアンモニウム塩 & 17 \\
\hline $\mathrm{NO}_{3}^{-}$ & $\begin{array}{l}\text { トリドデシルメチルアンモニウ } \\
\text { ム硝酸塩 }\end{array}$ & 20 \\
\hline $\mathrm{Ag}^{+}$ & チオェーテル環状化合物 & 21 \\
\hline $\begin{array}{l}\mathrm{Ag}^{+}, \mathrm{Co}^{2+}, \mathrm{Cd}^{2+}, \mathrm{Pb}^{2+} \\
\text { グルコン酸 }\end{array}$ & $\begin{array}{l}\text { カリックスアレン } \\
\text { ドデシルメチルアンモニウム. } \\
\text { グルコン酸 }\end{array}$ & $\begin{array}{l}22 \\
23\end{array}$ \\
\hline
\end{tabular}

案されている.

図 5 は異方性エッチングを用いて，機械的に有機膜を支 持する構造としたものである(5). 張合せ基板を用いてゲート を襄側に作って安定性の向上が同時に図られている. PVC にかわる材料として，シリコンゴム(19)やポリウレタン ${ }^{(26)}$, 漆(20)などを膜材料に用いたISFET が提案されている.こ れらはゲート絶緑膜との密着性がすぐれた材料である. 例え
ばシリコンゴム中にイオノフォアとしてノナクチンを固定化 したアンモニアセンサは，10-2 $10^{0} \mathrm{~mol} / \mathrm{m}^{3}$ の範囲に扣い て感度 $52 \mathrm{mV} / \mathrm{pNH}_{4}^{+}$で, FIA 測定にも使用でき約 $5.2 \mathrm{Ms}$ (2ケ月)以上にわたって安定であった ${ }^{(19)}$ ケポリウレタン ${ }^{(26)}$ を用いた ISFET では, 光架橋によりイオノフォアの固定化 が行われている. 光架橋性を利用寸れば，フォトリソグラフ ィ一技術が使えるため加工性に優れたセンサとなる.

共有結合によってイオン感応膜をゲート絶縁膜に結合した り，イオノフォアを支持膜に固定すれば安定性の向上が期待 できる.この研究は分子設計の手法を取り入れよらとするも ので，実用的なセンサを開発する立場からも注目されてい る.イオン感応膜とゲート絶縁膜を結合して安定化をはかっ た例としては，PVCに少量の $\mathrm{OH}$ 基を導入し，四塩化ケイ 素によりPVC膜とゲート絶縁膜とを結合させた例(27), PVCのかわりに，ポリ-HEMA (2-hydroxyethyl methacrylate)を用い，ゲート絶縁膜表面をオルガノシロキサンを介 してイオン感応膜と光化学反応で結合した $\mathrm{K}^{+}$センサ ${ }^{(28)}$ どがある.ゲート絶縁膜上にポリ-HEMA，ポリシロキサ ソ，イオノフォアを順次化学結合で固定した $\mathrm{K}^{+}$センサも開 発されている(29). 図 9 にポリシロキサンによるイオノフォ アとポリ-HEMA の結合状態を示す.

\section{ISFET バイオセンサ}

ISFET のダート絶縁膜上に酵素や抗体, 微生物などを固 定化したバイオセンサが開発されている. バイオセンサは生 物体の有する分子認識機能や化学反応触媒反応を利用するセ ンサであり，高感度で選択性にすぐれたセンサとなる。 ISFETを用いることにより，小型化，集積化などが可能と

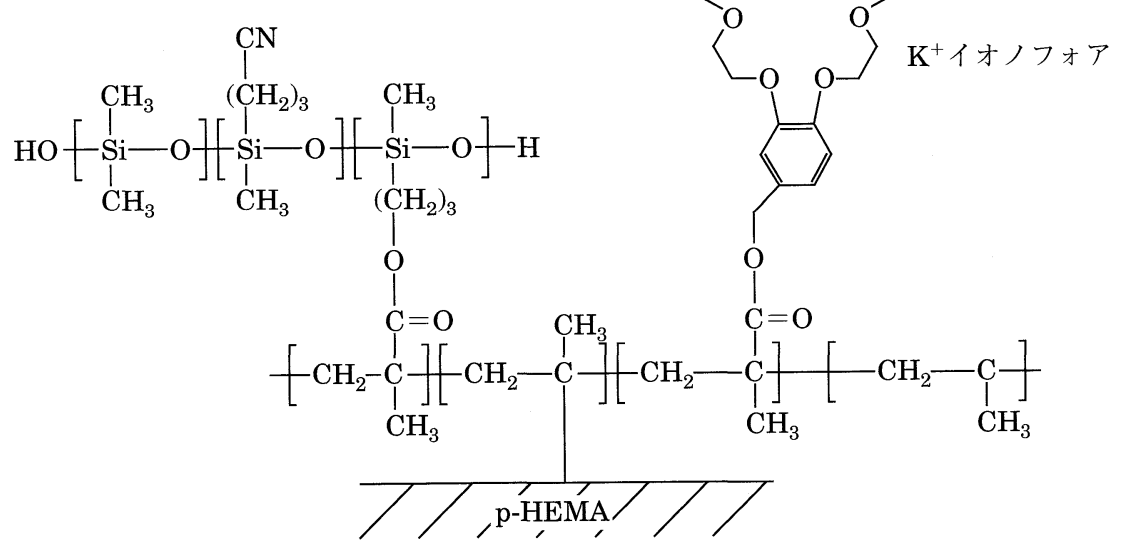

図 9 ゲート上に固定された有機膜(p-HEMA)に結合された $\mathrm{K}^{+}$イオノフォア. 
なるので臨床計測などで多くの用途がある. 一方酵素や抗体 は活性が失われやすく, 使用する量もわずかであるから安定 に固定化する技術が重要である.これまでに酵素センサで

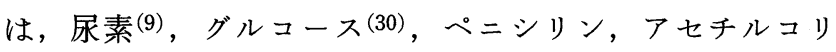
ン(31), アルコール(32)などのセンサが開発されている. 尿素 センサでは, 酵素としてウレアーゼを用いる．尿素はウレア 一ゼによって次式のように加水分解され $\mathrm{pH}$ が变化する.

$$
\mathrm{H}_{2} \mathrm{NCONH}_{2}+2 \mathrm{H}_{2} \mathrm{O}+\mathrm{H}^{+}=2 \mathrm{NH}_{4}+\mathrm{HCO}_{3}^{-}
$$

尿素センサはこの $\mathrm{pH}$ 変化を ISFET で検出している. FET 酵素センサでは, $\mathrm{pH}$ 変化を測定するものが多いが，アンモ ニアの濃度変化を測定する尿素センサや溶存酸素を測定する グルコースセンサも報告されている(33). 酵素の固定化には， アルブミンを固定化マトリックスとしてグルタルアルデヒド で架橋する方法が広く用いられている．安定性を向上するた め, 酵素をゲート絶縁膜表面に化学的に固定化する方法 ${ }^{(9)}$ や，ポリビニルブチラール膜等の新しいポリマーを使う方法 も提案されている(34). 高温でも失活しない好熱性の酵素を 用いて安定性の向上をはかったセンサもある(35).

集積化センサを作製するには, ゲート絶緑膜上の微小面積 に均一な酵素膜をつけるパターニング技術が重要となる．図
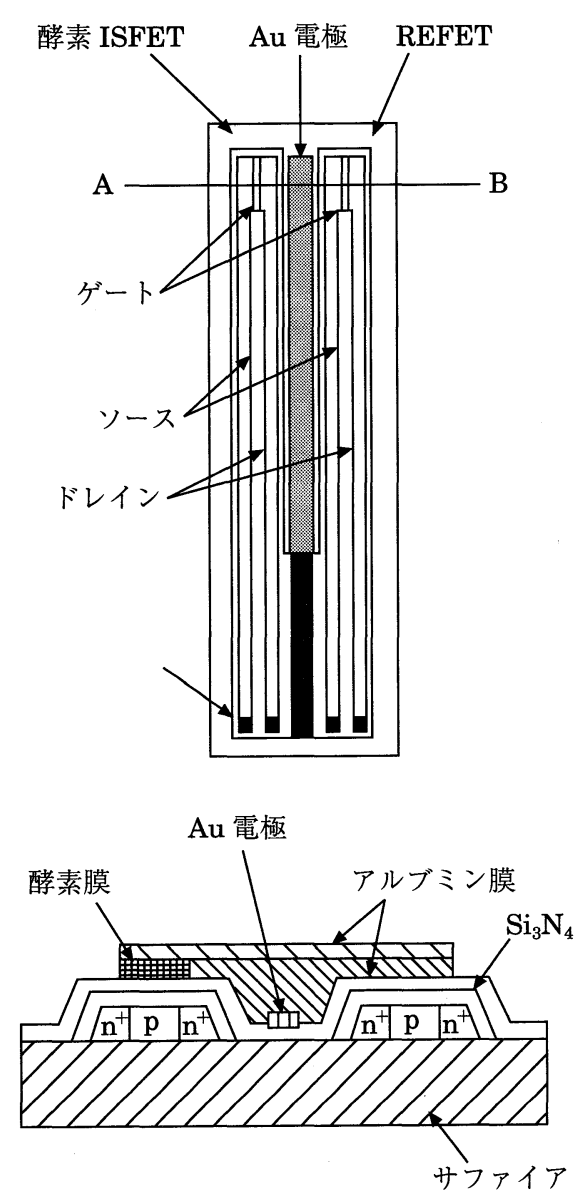

図10 ISFET グルコースセンサ.
10飞 SOS 基板を用いた ISFET 酵素センサの構造を示す(36). 一つのチップ上に 2 種類の ISFET と金電極が集積化された ものである． 2 個の ISFET の 1 個は GOD(グルコースオキ シダーゼ)を固定化したグルコースセンサであり，もら $1 つ$ は酵素を含まないアルブミン膜がコートされたものである. 金を参照極として使い, 2 つ FET の応答の差をとること によってグルュース濃度の測定を行うものである. GOD 膜 のパターニングはリフトオフ法で行ら. まずフォトレジスト で半導体表面をコートし，ゲート表面に空をあける．その上 から架橋剤を含んだ酵素溶液をスピンコートする. 酵素の架 橋が終わった後, 有機溶媒でフォトレジストを溶かし, 同時 に不必要な酵素膜を取り除く.この方法によれば微細なパタ ーニングが可能である. 酵素膜自身に光硬化性のレジストを 付加してパターニングする方法も提案されている(30).

\section{6. 溶存ガスセンサ}

$\mathrm{CO}_{2}$ や $\mathrm{O}_{2}$ などの溶存ガスセンサも ISFETを用いて開発 されている. $\mathrm{CO}_{2}$ センサとしては, 図11に示すように, ガ ス透過膜と pHISFET を組合せた構造のセンサが実用化さ れている. ゲート絶縁膜上に直接ガス透過膜を固定化した $\mathrm{CO}_{2}$ センサも報告されている.

$\mathrm{O}_{2}$ ガスセンサでは, $\mathrm{LaF}_{3}$ 薄膜を使らもの (33)や, $\mathrm{O}_{2}$ を睘 元し, この時生じる $\mathrm{pH}$ 変化を ISFET で測定するものなど が報告されている(37).

\section{ISFET の応用}

ISFET は，特に微量なサンプルによる計測や高速応答性 を生かした新しい応用に期待がかけられている，応用分野も 臨床計測や環境計測など多方面にわたっている. 特に臨床計 測用オンライン計測システムは, 安定性や自動校正法, 測定 の高速化, 生体適合性などについて多くの報告がある.また ISFET の高速応答性を活用したフローインジェクション分 析システムが種々の応用を目的として開発されている. 最近 はマイクロポンプを一体化した自動分析システムも報告され ている(39).

具体的な応用例としては，まず血液成分の分析に皮膚から の吸引によって採取される生体液を用いたセンサが開発され

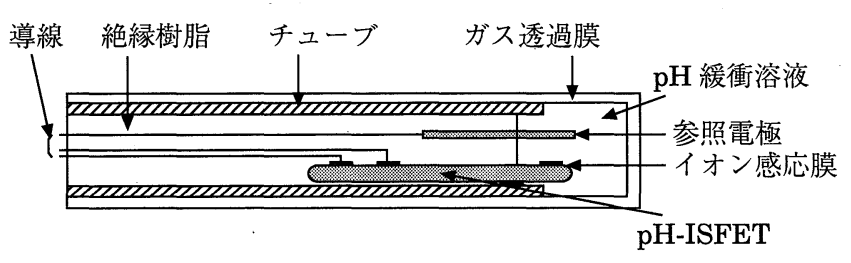

図11 pHISFET とガス透過膜を組合せた $\mathrm{pCO}_{2}$ センサ の構造 ${ }^{(40)}$. 
ている ${ }^{(38)}$. 微量 $\left(5 \mathrm{~mm}^{3}\right)$ な生体液を自動的に吸引, 採取, 測定，分析ができるシステムになっている．また微生物の代 謝による $\mathrm{pH}$ 変化を ISFET で測定する微生物測定用のセン サ，義歯に埋め込及口腔内歯垢中での $\mathrm{pH}$ 測定を行う虫歯研

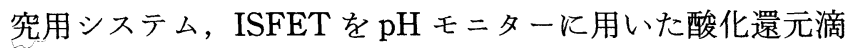
定実験システム，水耕栽培に打ける水質管理システム，など が開発されている.また熱帯魚などの水槽の水質管理にも使 用されている.

その他環境計測のためのセンサとして，酸性雨測定に使え る $\mathrm{pH}$ センサ, 硝酸センサが ISFET で開発されている ${ }^{(20)}$. また農薬污染の監視を目的とした殺虫剤のセンサが酵素(ア セチルコリン)センサの活性疎外効果を用いて開発された ${ }^{(31)}$.

\section{8. お わりに}

ISFET の研究報告は，1980年代を中心に膨大な数にのぼ る. それに対応して多数のイオンセンサが開発され, その応 用にも多くの期待がかけられた。 これらの一部はすでに実用 化されて扣り, 新しい応用分野も開拓されつつあるが，期待 の大きさに比べれば実用化されたものはまだそれ汪ど多くな い. 広い応用につながるためには, 現在応答の安定化にかか わる研究が最も重要である. そのためには応用分野の研究之 同時にセンシング機構の解明やイオン感応膜の安定な固定化 等にかかわる基礎的な研究が必要である.このよらな研究 は, 現在日本よりはむしろ欧米で地道な研究が続けられてい る. ISFET の初期の開発には日本が大きな貢献をしておうり, 技術の蓄積もあるため, 日本での研究の活性化も期待した い.

\section{文献}

(1) P. Bergveld: IEEE Trans. Biomed. Eng., 17(1970), 70.

（2）松尾正之, 江刺正喜: 応用物理, $49(1980), 586$.

(3) 伊藤善孝 : CHEMICAL SENSORS, 9(1993), 53.

（4）栗山敏秀, 木村 純, 川名美江：信学技報, ED84-158(1985), 19.

( 5 ) H. Yagi and T. Sakai: Sensors and Actuators B, 13-14(1993), 212.

(6) K. Chen, G. Li, H. Lu and L. Chen: Sensors and Actuators B, 12 (1993), 23.

( 7 ) M. Klein: Sensors and Actuators, 17(1989), 203.

( 8 ) A. van den Berg, A. Grisel, H. H. van den Vlekkert and N. F. de Rooji: Sensors and Actuators, B1 (1990), 425.

( 9 ) P. Clechet, N. Jaffrezic-Renault and C. Martelet: Chemical Sensor Technology, Kodansha LTD(Tokyo), Vol. 4, (1992), 205.

(10) T. Ito, H. Inagaki and I. Igarashi: IEEE Trans. Electron Devices, ED-35 (1988), 56.

(11) M. J. Schoning, M. Bruns, W. Hoffmann, B. Hoffmann and H. J. Ache: Sensors and Actuators B, 15-16(1993), 192.

(12) W. Moritz, B. H. van der Schoot, N. F. de Rooji, H. H. van den Vlekkert and H. C. G. Ligtenberg: Sensors and Actuators B, 13-14(1993), 217.
(13) Yu. A. Tarantov, Yu. G. Vlasov, Yu. A. Mesentsev and Y. L. Averyanov: Sensors and Actuators, B1(1990), 390.

(14) T. Nomura and K. Masui: Bull. Chem. Soc. Jpn., 65(1992), 2338.

(15) A. Bouazizi, H. Maaref, N. Jaffrezic-Renault, R. B. Chaabane, M. Gamoudi and G. Guillaud: Digest of Technical Papers Transducers'95 - Eurosensors X, 490-PD12, (1995), 974.

(16) S. Wakida, Y. Kohigashi, K. Higashi and Y. Ujihira: Digest of Technical Papers Transducers'95-Eurosensors X, 475-D12, (1995), 925.

(17) K. Tsukada, Y. Miyahara, Y. Shibata and H. Miyagi; Sensors and Actuators B, 2(1990), 291.

(18) S. Wakida, M. Yamane and K. Hiiro: Sensors and Actuators, 2 (1988), 107.

(19) S. Ufer and K. Cammann: Sensors and Actuators B, 7(1992), 572.

（20）脇田慎一：センサ技術，12, No. 8 (1992), 33.

(21) Z. Brzozka, P. L. H. M. Cobben, D. N. Reinhoudt, J. J. H. Edema, J. Buter and R. M. Kellogg: Anal. Chim. Acta, 273(1993), 139.

(22) P. L. H. M. Cobben, R. J. M. Egberink, J. G. Bomer, P. Bergverd, W. Verboom and D. N. Reinhoudt: J. Am. Chem. Soc., 114(1992), 10573.

（23）日色和夫, 向井 浩, 脇田慎一, 丸亀和雄 : BUNSEKI KAGAKU, 42(1993), 509.

(24) S. D. Moss, J. Janata and C. C. Johnson: Anal. Chem., 47 (1975), 2238.

(25) W. P. R. V. Stauthamer, J. F. J. Engbersen, W. Verboom and D. N. Reinhoudt: Sensors and Actuators B, 17(1994), 197.

(26) A. Bratov, N. Abramova, V. Munoz, C. Dominguez, S. Alegret, J. Bartroli and Yu. Vlasov: Digest of Technical Papers Transducers'95-Eurosensors X, 222-PD6, (1995), 874.

(27) D. J. Harrison, A. Teclemariam, L. L. Cunningham: Anal. Chem., 61 (1989), 246.

(28) M. Battilotti, R. Colilli, I. Giannini and M. Giongo: Sensors and Actuators, 17(1989), 209.

(29) Z. Brzozka, H. A. J. Holterman, G. W. N. Honig, U. H. Verkerk, H. H. van den Vlekkert, J. F. J. Engbersen and D. N. Reinhoudt: Sensors and Actuators B, 18-19(1994), 38.

(30) Y. Hanazato, M. Nakako, S. Shiono and M. Maeda: IEEE Trans. Electron Devices, 36(1989), 1303.

(31) H. Sakai, N. Kaneki and H. Hara: Sensors and Actuators B, 13-14(1993), 578.

(32) T. Kullick, U. Bock, J. Schubert, T. Scheper and K. Schugerl: Anal. Chim. Acta, 300(1995), 25.

(33) T. Katsube, T. Kubota, M. Shimizu, N. Matayoshi, N. Miura and N. Yamazoe: Jpn. J. Appl. Phys., 30(1991), L871.

(34) M. Gotoh, E. Tamiya and I. Karube: Sensors and Materials, 1(1988), 25 .

（35）川辺 健, 飯田武揚, 野口文雄, 三田村 孝, 勝部昭明, 富田 耕右：日本化学会誌, 1987 (1987), 1719 .

(36) T. Kuriyama: Digest of Technical Papers Transducers'95-Eurosensors X, 108-C1 (1995), 447.

(37) C. S. Kim, D. H. Kwon and B. K. Sohn: Digest of Technical Papers Transducers'95-Eurosensors X, 472-PD11(1995), 913.

（38）兼吉昭雄, 村上志緒, 西田時次, 岩崎博信, 萱嶋信介, 荒井 恒憲, 菊地 真 : 信学技報, CPM95-27.

(39) W. Gumbrecht, W. Schelter, B. Montag, M. Rasinski and U. Pfeiffer: Sensors and Actuators, B1(1990), 477.

（40）脇田慎一：絶緑体材料,「センサー材料のやさしい知識」, 春田正毅，鈴木義彦，山添 曻編，才ーム社，P. 133(1995). 